\title{
Short ingestion tests as alternative proposal for conventional range finding assays with Thamnocephalus platyurus and Brachionus calyciflorus
}

\author{
* G. Natęcz Jawecki; L. Szczęsny; D. Solecka; J. Sawicki \\ Department of Environmental Health Sciences, Medical University of Warsaw, Banacha 1, 02-097 Warsaw, Poland
}

Received 16 January 2011; revised 15 June 2011; accepted 10 August 2011

\begin{abstract}
ABSRACT: The goal of this study was to evaluate whether short $1 \mathrm{~h}$ sublethal assays may predict the results of 24 $\mathrm{h}$ lethality assays with rotifers Brachionus calyciflorus and anostracan crustaceans Thamnocephalus platyurus. The test bionts were hatched from cysts. Inhibition of ingestion was observed after $15 \mathrm{~min}$ of incubation of rotifers and crustaceans with the suspension of carmine and latex beads, respectively. Nine compounds with different modes of action were used as toxicants zinc ions, sodium dodecyl sulphate, p-nitrophenol, 3, 5-dichlorophenol and pharmaceuticals propranolol, fluoxetine, abamectin, doramectin and ivermectin. The toxicity values observed in the ingestion tests were very close to the mortality values over a wide range of toxicity from a low toxic surfactant to very toxic avermectins. The ratio between the $1 \mathrm{~h} \mathrm{EC}_{50}$ 's in the ingestion test and the $24 \mathrm{~h} \mathrm{LC}_{50}$ 's in the lethality test was below 2 in all cases for rotifers, and 7 in 9 cases for crustaceans. The toxicity of zinc and 3,5-dichlorophenol in the Thamnotoxkit FTM $^{\mathrm{TM}}$ was 15 -fold higher and 10 fold lower than in the ingestion test, respectively. The $24 \mathrm{~h} \mathrm{LC}_{50}$ values are within the range of 25$400 \%$ of the $1 \mathrm{~h} \mathrm{EC}_{50}$ values for almost all toxicants tested with the exception of p-nitrophenol for B. calyciflorus and zinc and 3,5-dichlorophenol for T. platyurus. Short, $1 \mathrm{~h}$ ingestion assays Rotoxrapid and Rapidtoxkit are good predictors of the mortality over the next $24 \mathrm{~h}$ and can be used as a range finding tests for representatives of pharmaceuticals and surfactants.
\end{abstract}

Keywords: Avermectins; Bioassay; Ingestion assay; Pharmaceuticals in the environment; Toxkit

\section{INTRODUCTION}

Rotifers and crustaceans play an important role in many aquatic ecosystems as suspension feeders. With their high assimilation efficiencies, rotifers convert a considerable portion of their food into biomass (Snell and Janssen, 1995). On the other hand, they are often the first food for many larval fish. They are an important link between the nanoplankton and macrozooplankton. Rotifers, especially the genus Brachionus, have been used in ecological studies as early as the 1970s. In 1989, a standard toxkit protocol with Brachionus calyciflorus was proposed by the group of Prof. Persoone from the University of Ghent in Belgium (Snell and Persoone, 1989) and two years later, in 1991 an ASTM standard acute toxicity test was published (ASTM, 1991). Since then, rotifers in ecotoxicological studies have been used more often (Snell and Janssen, 1995; Preston et al., 2001; Sanchez-

*Corresponding Author Email: gnalecz@wum.edu.pl Tel.:+4822-5720-740; Fax: +4822-5720-738
Fortun and Barahona, 2005;Dahms et al., 2011). Anostracan crustacean Thamnocephalus platyurus has been used in ecotoxicology for 15 years (Centeno et al., 1995). Its high sensitivity has been shown in many kinds of samples including pesticides (Fochtman et al., 2000; Bakuolia et al., 2008; Palma et al., 2008), cyanobacterial toxins (Törökné et al., 2000) and pharmaceuticals ( $\mathrm{Na}^{3}$ êcz-Jawecki and Persoone, 2006; DellaGreca et al., 2007; Kim et al., 2009).

Ingestion is an ecologically important behaviour that directly affects growth and reproduction. A feeding activity can be assessed by allowing a small population to feed on unicellular algae or special artificial food. An ingestion rate may be a good estimator of toxicity in suspension-feeding microinvertebrates. One of the main advantages of the ingestion assay is its speed (Snell, 2005). An ingestion test with rotifers was developed in 1994 (Juchelka and Snell, 1994) and refined ten years later (Snell, 2005). 
Rapidtoxkit test utilises larvae of anastracan $T$. platyurus freshly hatched from the dormant cysts. In the Rapidtoxkit assay the sublethal physiological reaction of the organisms to toxic stress is assessed by introducing a suspension of red latex beads $(5 \mu \mathrm{m})$ in the test medium following a $1 \mathrm{~h}$ exposure of the organisms to the toxicant, and by observing the presence or absence of coloration of the digestive tract under a dissection microscope. The test was introduced by MicroBioTests in 2004 as a screening tool for water contamination emergencies resulting from accidental or deliberate introduction of toxicants in water supplies (Rapidtoxkit, 2004; Törökné et al., 2007).

Standard acute lethality assays last at least $24 \mathrm{~h}$, and when testing unknown samples, they require preliminary range finding tests, which prolong the time of analysis by additional $24 \mathrm{~h}$. Moreover, the new set of larvae should be hatched from the cysts, which double the cost of analysis. The goal of this paper is to evaluate whether a short $1 \mathrm{~h}$ sublethal assay may predict the results of the $24 \mathrm{~h}$ lethality assay, and whether this test may be used as a range finding test. Three groups of toxicants were chosen due to their widespread detection in environmental samples: metals (Reza and Singh, 2010), simple organics and pharmaceuticals (Giri et al., 2010).

\section{MATERIALS AND METHODS}

\section{Chemicals}

Nine compounds were tested as toxicants, namely zinc ions (as $\mathrm{ZnSO}_{4}$ pure p.a., POCh, Poland), sodium dodecyl sulphate (SDS specially pure, Serva), pnitrophenol (PNP pure p.a., Sigma), 3,5-dichlorophenol (DCP $97 \%$, Sigma), propranolol (PL analytical standard, Sigma), fluoxetine (FLU analytical standard, Sigma), abamectin (ABM analytical standard, Sigma), doramectin (DOM analytical standard, Sigma) and ivermectin (IVM analytical standard, Sigma). The last three compounds are hardly soluble in water, thus stock solutions $(1 \mathrm{mg} / \mathrm{mL})$ were prepared in methanol, and the working solutions were prepared by dilution the stock solutions in diluent (moderately hard US EPA medium, EPA, 2002).

In the tests with rotifers and anostracans, the suspension of carmine (Sigma) and red latex beads (MicroBioTests, Belgium) respectively were used as artificial food.
Toxicity tests

Thamnotoxkit $F^{\mathrm{TM}}$

The Thamnotoxkit FTM microbiotest is a $24 \mathrm{~h}$ acute lethal toxicity test with anostracan crustacean Thamnocephalus platyurus. Organisms were hatched from dormant cysts after $24-40 \mathrm{~h}$ incubation at $25^{\circ} \mathrm{C}$ in synthetic freshwater (moderately hard US EPA medium, EPA, 2002) under continuous illumination (3000-4000 lux). The assays were carried out in 24 well multiplates according to the standard operational procedure for this microbiotest (Thamnotoxkit FTM , 1995). In each plate five concentrations of sample plus negative control were tested. Samples were prepared in 2-fold dilution series in three replicates with ten animals having been added to each well that contained $1.0 \mathrm{~mL}$ of tested dilution. After $24 \mathrm{~h}$ of incubation at $25^{\circ} \mathrm{C}$ in the dark the dead organisms were counted. On the basis of the percentage of mortality the $24 \mathrm{~h} \mathrm{LC}_{50}$ and $24 \mathrm{~h} \mathrm{LC}_{20}$ were calculated with a graphical interpolation method (EPA, 2002).

\section{Rapidtoxkit - ingestion test with T. platyurus}

The test was based on the Rapidtoxkit protocol (Rapidtoxkit, 2004) with modifications ( $\mathrm{Na}^{3}$ êcz-Jawecki and Persoone, 2006). Shortly, the test was performed in 12 well multiplates. Each well contained $5 \mathrm{~mL}$ of the dilution of the sample and 20 testbionts. The $T$. platyurus larvae should be older than in the mortality test (hatching should last 30-40 h). After $1 \mathrm{~h}$ incubation in darkness at $25^{\circ} \mathrm{C}$ the suspension of red latex beads was added. The crustacea fed on artificial food for 15 min, then they were killed by one drop of Lugol solution. The number of intoxicated larvae in each concentration was counted with the use of dissection microscope (10x magnification). The organism was counted as intoxicated, when its digestive track was colourless, without any red particles (Fig. 1). On the basis of the percentage of affected crustaceans $1 \mathrm{~h} \mathrm{EC} \mathrm{E}_{50}$ and $1 \mathrm{~h} \mathrm{EC} \mathrm{EC}_{20}$ values were calculated with graphical interpolation method (EPA, 2002).

\section{Rotoxkit $F^{\mathrm{TM}}$ with modifications}

The Rotoxkit $\mathrm{F}^{\mathrm{TM}}$ microbiotest is a $24 \mathrm{~h}$ acute lethal toxicity test with freshwater rotifer Brachionus calyciflorus. Organisms were hatched from dormant cysts after $16-18 \mathrm{~h}$ incubation at $25{ }^{\circ} \mathrm{C}$ in synthetic freshwater (moderately hard US EPA medium, EPA, 1993) under continuous illumination (3000-4000 lux). The assays were performed according to the standard 

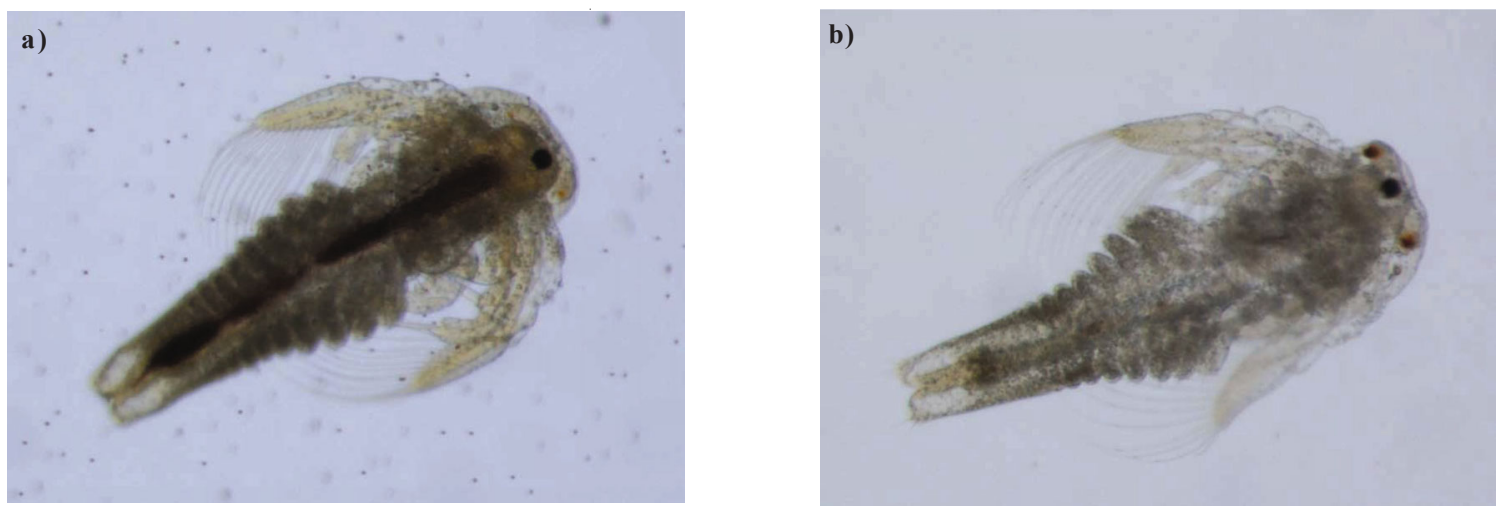

Fig. 1: Rapidtoxkit assay with Thamnocephalus platyurus. Larvae with artificial food (a) and affected larvae with colorless digestive track (b)

operational procedure for this microbiotest (Rotoxkit FTM, 2000) with modifications. Disposable polistyrene 48-well multiplates were used as test containers. Two samples may be tested in one plate, five concentrations of each plus negative control. Samples were prepared in 2-fold dilution series in three replicates, and ten animals were added to each well containing $0.5 \mathrm{ml}$ of tested dilution. After $24 \mathrm{~h}$ incubation at $25^{\circ} \mathrm{C}$ in the dark, the dead rotifers were counted. On the basis of the percentage of mortality, the $24 \mathrm{~h}-\mathrm{LC}_{50}$ and $24 \mathrm{~h}-\mathrm{LC}_{20}$ were calculated with a graphical interpolation method (EPA, 2002).

\section{RotoxRapid - ingestion test with B. calyciflorus}

The test was performed in a 48 well multiplate and the preparation of the plate was the same as in the mortality test. After $1 \mathrm{~h}$ incubation in darkness at $25{ }^{\circ} \mathrm{C}$, the suspension of carmine was added. The final suspension of carmine in the test wells was $5,000 / \mathrm{mL}$. Rotifers fed on the carmine particles for $15 \mathrm{~min}$, after which they were killed by one drop of Lugol solution. The number of feeding and non-feeding rotifers in each concentration was counted with the use of dissection microscope (20x magnification). On the basis of the percentage of nonfeeding rotifers $1 \mathrm{~h}-\mathrm{EC}_{50}$ and $1 \mathrm{~h}-\mathrm{EC}_{20}$ values were calculated. There was no distinction for the intensity of the particle uptake during the calculation of the number of organisms which took coloured particles (Fig. 2).

\section{RESULTS AND DISCUSSION}

\section{Brachionus calyciflorus}

B. calyciflorus was the most sensitive to FLU with the $\mathrm{LC}_{50}$ below $1 \mathrm{mg} / \mathrm{L}$ (Table 1). Zinc ions, DCP and other pharmaceuticals with the $\mathrm{LC}_{50}$ values between 1 and 10 $\mathrm{mg} / \mathrm{L}$ are classified as toxic, while SDS was harmful to the rotifer with the $\mathrm{LC}_{50}$ value between 10 and 100 $\mathrm{mg} / \mathrm{L}$. However, the partial mortality was caused by lower concentrations of SDS, and the threshold toxicity values $\left(24 \mathrm{~h}-\mathrm{LC}_{20}\right)$ for all toxic compounds were below $10 \mathrm{mg} / \mathrm{L}$. PNP did not cause lethal effects in all concentrations up to $20 \mathrm{mg} / \mathrm{L}$.

The toxicity values observed in the RotoxRapid were very close to the mortality values. The ratio between the $1 \mathrm{~h}-\mathrm{EC}_{50}$ 's in the ingestion test and the $24 \mathrm{~h}-\mathrm{LC}_{50}$ 's in the lethality test was below 2 for all compounds tested (Table 1 and Fig. 3). Slightly more pronounced differences between the two assays were observed for $\mathrm{EC}_{20}$ and $\mathrm{LC}_{20}$ values. The $\mathrm{EC}_{20} / \mathrm{LC}_{20}$ ratio was higher than the $\mathrm{EC}_{50} / \mathrm{LC}_{50}$ ratio in the case of 5 out of 9 toxicants tested, reaching the values of 2.36 and 2.06 for PL and FLU, respectively (Table 1). Contrary to that, $\mathrm{Zn}$ and SDS affected rotifers' ingestion of the carmine at the levels lower than the lethal concentration. This phenomenon may be explained by the induction of the resistance to toxicants. As it is known, metalothioneins which are responsible for the resistance to metals of many animals, have not been reported in rotifers yet. The toxic stress caused by PNP after $1 \mathrm{~h}$ was not observed in the Rotoxkit FTM assay in all concentrations up to $20 \mathrm{mg} / \mathrm{L}$. Thus, the toxicity endpoints cannot be calculated. The volatile organic compounds should be tested with a special procedure ( $\mathrm{Na}^{3}$ êcz-Jawecki and Sawicki, 1999). However, volatility can not be the only reason for the decrease of PNP toxicity, since in the case of DCP the results of both assays with rotifer are similar. 

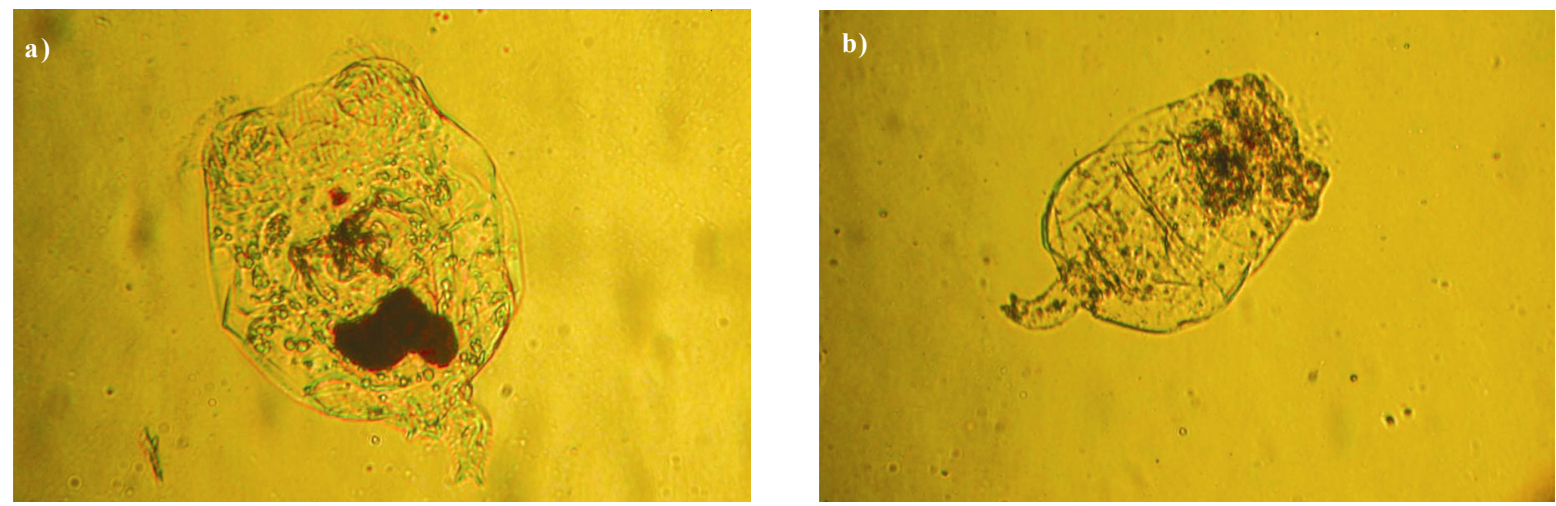

Fig. 2: Ingestion assay with Brachionus calyciflorus. Rotifer with artificial food (a) and affected rotifer with colorless digestive track (b)

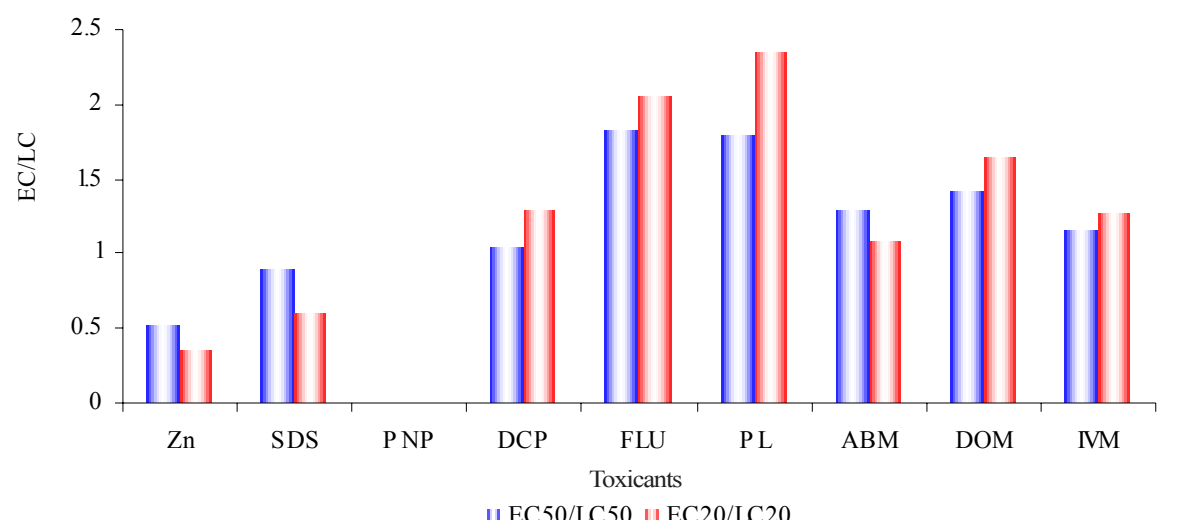

Fig. 3: The ratio of the toxicity values in the ingestion test to the mortality test (I/M) for $B$. calyciflorus

Table 1: The toxicity of 9 chemicals towards the rotifer Brachionus calyciflorus

\begin{tabular}{|c|c|c|c|c|c|c|c|c|c|c|c|}
\hline \multirow{2}{*}{ Toxicant } & \multirow{2}{*}{ Abbreviation } & \multicolumn{4}{|c|}{ Ingestion test $(\mathrm{mg} / \mathrm{L})$} & \multicolumn{4}{|c|}{ Mortality test (mg/L) } & \multicolumn{2}{|c|}{$\mathrm{I} / \mathrm{M}^{*}$} \\
\hline & & $1 \mathrm{~h}-\mathrm{EC}_{50}$ & SD & $1 \mathrm{~h}-\mathrm{EC}_{20}$ & SD & $24 \mathrm{~h}-\mathrm{LC}_{50}$ & SD & $24 \mathrm{~h}-\mathrm{LC}_{20}$ & SD & $\mathrm{EC}_{50} / \mathrm{LC}_{50}$ & $\mathrm{EC}_{20} / \mathrm{LC}_{20}$ \\
\hline Zinc $\left(\mathrm{Zn}^{2+}\right)$ & $\mathrm{Zn}$ & 2.15 & 0.47 & 0.88 & 0.56 & 4.10 & 1.69 & 2.51 & 0.99 & 0.52 & 0.35 \\
\hline SDS & SDS & 12.22 & 3.53 & 5.44 & 3.73 & 13.78 & 4.92 & 9.08 & 5.65 & 0.89 & 0.60 \\
\hline p-nitrophenol & PNP & 12.75 & 0.10 & 8.80 & 0.10 & $>20$ & - & $>20$ & - & - & - \\
\hline 3,5-dichlorophenol & DCP & 5.27 & 2.00 & 4.04 & 1.70 & 5.08 & 1.20 & 3.14 & 1.20 & 1.04 & 1.29 \\
\hline Fluoxetine & FLU & 0.97 & 0.34 & 0.64 & 0.39 & 0.53 & 0.26 & 0.31 & 0.12 & 1.83 & 2.06 \\
\hline Propranolol & PL & 3.88 & 0.48 & 2.76 & 0.13 & 2.15 & 0.58 & 1.17 & 0.37 & 1.80 & 2.36 \\
\hline Abamectin & $\mathrm{ABM}$ & 3.08 & 0.40 & 2.31 & 0.76 & 2.38 & 0.81 & 2.11 & 0.94 & 1.29 & 1.09 \\
\hline Doramectin & DOM & 2.86 & 0.32 & 1.70 & 0.48 & 2.03 & 1.04 & 1.03 & 0.52 & 1.41 & 1.65 \\
\hline Ivermectin & IVM & 1.81 & 0.29 & 1.31 & 0.22 & 1.57 & 0.08 & 1.04 & 0.22 & 1.15 & 1.26 \\
\hline
\end{tabular}

* - Ratio of the toxicity value in the ingestion test to that in the mortality test 
The ingestion ratio in the test with rotifers is an excellent predictor of the mortality over the next $24 \mathrm{~h}$. The dilution series of a sample tested in the standard Rotoxkit FTM assay comprises five 2 fold concentrations. If the highest concentration tested in Rotoxkit $\mathrm{F}^{\mathrm{TM}}$ is equal to $400 \%$ of $1 \mathrm{~h} \mathrm{EC} \mathrm{EC}_{50}$, both toxicity values $24 \mathrm{~h}-\mathrm{LC}_{50}$, and $24 \mathrm{~h}-\mathrm{LC}_{20}$, are within the range of tested dilutions (Fig. 4). The only exception was PNP, which did not cause the mortality in all tested concentrations.

\section{Thamnocephalus platyurus}

The anostracan crustacean T. platyurus was extremely sensitive to antihelminthic pharmaceuticals. The $24 \mathrm{~h} \mathrm{LC}_{50}$ values were 5.7, 8.9 and $13.2 \mu \mathrm{g} / \mathrm{L}$ for IVM, DOM and ABM, respectively (Table 2). A $1 \mathrm{~h}$ incubation in Rapidtoxkit at concentration of $20 \mu \mathrm{g} / \mathrm{L}$ of the drug was enough to observe a lethal response (data not presented). These compounds generated also very low threshold toxicity values, which were 3.4 to 4.7 fold lower than the $1 \mathrm{~h} \mathrm{EC}_{50}$. Avermectins enhance inhibitory neurotransmission by activating glutamate-gated chloride channels in neurons and myocytes. The results clearly show that bioavailability of the compounds is very high and the neurotoxic action is very fast. However, to some degree, the inhibitory effect was reversible and did not cause death of the organism. Thus, for these toxicants the $1 \mathrm{~h} \mathrm{EC} / 24 \mathrm{~h} \mathrm{LC}$ ratios were below 1 . Zinc ions and FLU were very toxic to the crustacean with $24 \mathrm{~h}-\mathrm{LC}_{50}$ values below $1 \mathrm{mg} / \mathrm{L}$, while SDS and PNP were considered as harmful with $24 \mathrm{~h}-\mathrm{LC}_{50}$ 's of 15.1 and $27.4 \mathrm{mg} / \mathrm{L}$, respectively.
Like in the case of the rotifer assays, the ratio between the $1 \mathrm{~h} \mathrm{EC}$ s0's in the ingestion test and the $24 \mathrm{~h}-\mathrm{LC}_{50}$ 's in the lethality test was below 2 for almost all compounds tested. However, there were two exceptions. The toxicity of $\mathrm{Zn}$ drastically increased over the time of incubation. Both median and threshold toxicity values in the Thamnotoxkit $\mathrm{F}^{\mathrm{TM}}$ were 15 and 18 fold lower than in the ingestion test (Table 2 and Fig. 5). On the other hand, DCP affected the ingestion of T. platyurus in the concentrations 10 -fold lower than the lethal levels. The reason for this recovery cannot be explained by the high volatility of the compound. PNP with the similar vapour pressure was only 2-fold more toxic in the Rapidtoxkit compared to Thamnotoxkit FTM. The Rapidtoxkit assay is a good predictor of the mortality over the next $24 \mathrm{~h}$. The $24 \mathrm{~h} \mathrm{LC}_{50}$ 's are within the range of $25-400 \%$ of the $1 \mathrm{~h} \mathrm{EC} \mathrm{E}_{50}$ values for 7 out of 9 toxicants tested (Fig. 6). Due to the high $24 \mathrm{~h} \mathrm{LC}_{50} / \mathrm{LC}_{20}$ ratio, the $24 \mathrm{~h} \mathrm{LC}_{20}$ values are outside this range in 4 cases. Nowadays, it is a great challenge to create a quick and simple test method for detecting toxicity of various samples including unknown chemical substances and environmental samples. Acute toxicity tests with rotifer $B$. calyciflorus and anostracan T. platyurus have been used in many ecotoxicological laboratories due to their cost-effectiveness and high sensitivity to various toxicants. They seem to be useful tools of the risk assessment for pharmaceuticals and their metabolites that find their way into aquatic ecosystems because of their high sensitivity to some of these substances ( $\mathrm{Na}^{3} \mathrm{e} \mathrm{cz}-\mathrm{Jawe}$ eki and Persoone, 2006; Snell and Joaquim-Justo, 2007). B. calyciflorus and T.

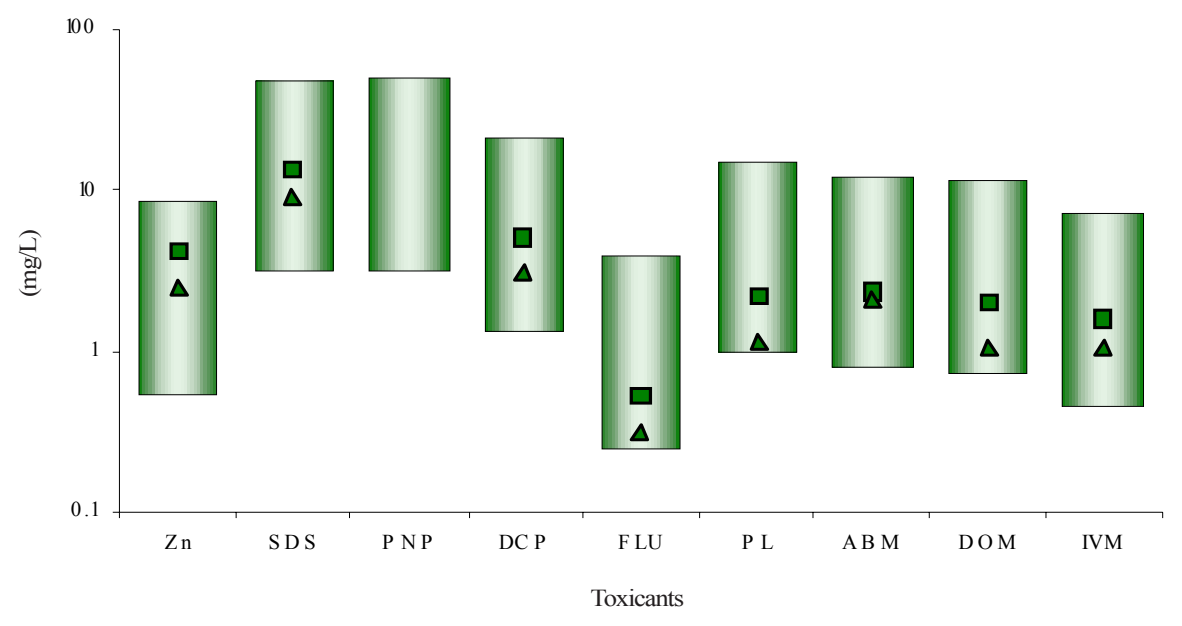

Fig. 4: Comparison of concentrations used in the ingestion test with rotifers (bars) with the $24 \mathrm{~h}$ $\mathrm{LC}_{50}(\square)$ and $24 \mathrm{~h}-\mathrm{LC}_{20}(\boldsymbol{\Delta})$ values in the Rotoxkit $\mathrm{F}^{\mathrm{TM}}$ assay. Bars comprise the concentrations of $400-25 \%$ of the $1 \mathrm{~h}-\mathrm{EC}_{50}$ for each toxicant 
G. Nalecz Jawecki et al.

Table 2: The toxicity of 9 chemicals towards the anostracean Thamnocephalus platyurus

\begin{tabular}{|c|c|c|c|c|c|c|c|c|c|c|c|}
\hline \multirow{2}{*}{ Toxicant } & \multirow{2}{*}{ Abbreviation } & \multicolumn{4}{|c|}{ Ingestion test $(\mathrm{mg} / \mathrm{L})$} & \multicolumn{4}{|c|}{ Mortality test (mg/L) } & \multicolumn{2}{|c|}{$\mathrm{I} / \mathrm{M}^{*}$} \\
\hline & & $1 \mathrm{~h}-\mathrm{EC}_{50}$ & $\mathrm{SD}$ & $1 \mathrm{~h}-\mathrm{EC}_{x}$ & $\mathrm{SD}$ & $24 \mathrm{~h}-\mathrm{LC}_{50}$ & $\mathrm{SD}$ & $24 \mathrm{~h}-\mathrm{LC}_{20}$ & SD & $\mathrm{EC}_{50} / \mathrm{LC}_{50}$ & $\mathrm{EC}_{2} \alpha \mathrm{LC}_{20}$ \\
\hline Zinc & $\mathrm{Zn}$ & 5.00 & 1.01 & 2.90 & 0.81 & 0.33 & 0.03 & 0.16 & 0.04 & 15.15 & 18.12 \\
\hline SDS & SDS & 21.20 & 8.01 & 12.60 & 5.30 & 15.1 & 4.84 & 7.96 & 2.32 & 1.40 & 1.58 \\
\hline p-nitrophenol & PNP & 12.80 & 0.76 & 5.76 & 0.58 & 27.4 & 1.20 & 12.30 & 2.80 & 0.47 & 0.47 \\
\hline 3,5-dichlorophenol & DCP & 0.34 & 0.01 & 0.18 & 0.03 & 3.02 & 0.42 & 2.09 & 0.36 & 0.11 & 0.09 \\
\hline Fluoxetine & FUU & 1.60 & 0.60 & 0.68 & 0.21 & 0.85 & 0.11 & 0.42 & 0.13 & 1.88 & 1.62 \\
\hline Propranolol & PL & 5.50 & 0.55 & 2.83 & 0.73 & 3.24 & 0.09 & 1.68 & 0.18 & 1.70 & 1.68 \\
\hline Abamectin & $\mathrm{ABM}$ & 0.0100 & 0.0005 & 0.0023 & 0.0005 & 0.0132 & 0.0015 & 0.0033 & 0.0011 & 0.76 & 0.70 \\
\hline Doramectin & DOM & 0.0072 & 0.0014 & 0.0021 & 0.0005 & 0.0089 & 0.0014 & 0.0035 & 0.0012 & 0.81 & 0.60 \\
\hline Ivermectin & IVM & 0.0052 & 0.0011 & 0.0011 & 0.0003 & 0.0057 & 0.0012 & 0.0033 & 0.0011 & 0.91 & 0.33 \\
\hline
\end{tabular}

* - ratio of the toxicity value in the ingestion test to that in the mortality test

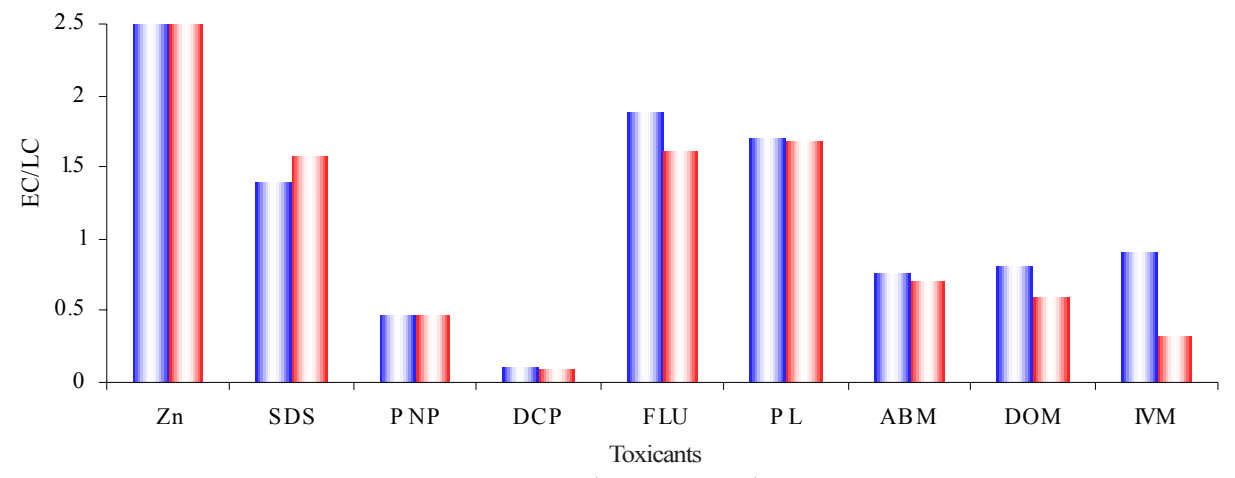

|| EC50/LC50 || EC20/LC20

Fig. 5: The ratio of the toxicity values in the ingestion test to the mortality test for T. platyurus

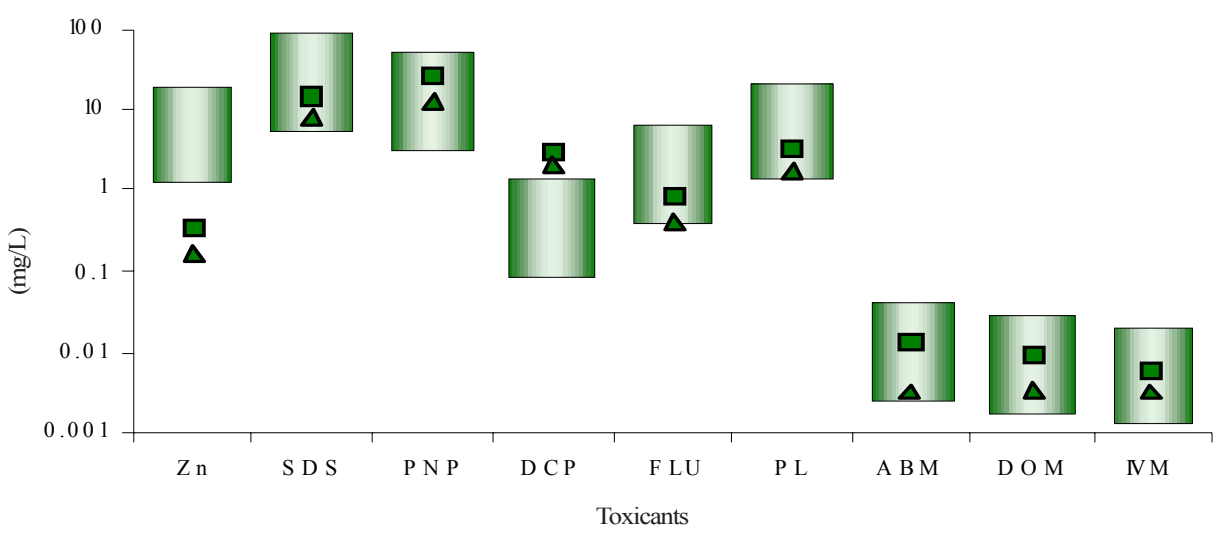

Fig. 6: Comparison of concentrations used in the Rapidtoxkit FTM (bars) with the $24 \mathrm{~h} \mathrm{LC}_{50}(\square)$ and 24 h- $\mathrm{LC}_{20}(\boldsymbol{\Delta})$ values in the Thamnotoxkit $\mathrm{F}^{\mathrm{TM}}$ assay. Bars comprise the concentrations of $400-25 \%$ of the $1 \mathrm{~h} \mathrm{EC}_{50}$ for each toxicant 
platyurus were applied by Isidori et al. (2005) to evaluate the ecotoxicity of naproxen and its photoproducts.

Conventional assays with animals last at least $24 \mathrm{~h}$, and require preliminary, range finding tests, which prolong the time of analysis by additional $24 \mathrm{~h}$. At the end of the $20^{\text {th }}$ century new biotests were developed with a very short time of exposure of planktonic crustaceans. The principle of the Fluotox (Janssen and Persoone, 1993) and IQ Toxicity Test ${ }^{\mathrm{TM}}$ (Hayes et al., 1996) is an in vivo detection of enzymatic inhibition, visualised by fluorescence of the whole organism under a UV light source. For Daphnia, the 1-h enzymatic inhibition (expressed as $\left.1 \mathrm{~h}-\mathrm{EC}_{50}\right)$, very well correlated $(\mathrm{r}=0.8)$ with the immobilization $48 \mathrm{~h}-\mathrm{EC}_{50}$ for 20 compounds (Persoone, 1992).

Ingestion tests are based on a well known reaction of filter-feeding biota, i.e. stopping of ingestion of food (or artificial particles) when exposed to a toxic stress ( $\mathrm{Na}^{3} \mathrm{e} \mathrm{cz}-$ Jawecki and Persoone, 2006). The ingestion ratio has been applied as an endpoint in toxicity assays with protozoans (Juchelka and Snell, 1995), rotifers (Juchelka and Snell, 1994), crustaceans (De Coen et.al., 1998) and anostraceans (Rapidtoxkit, 2004). De Coen et al. (1998) discovered a very significant $(\mathrm{r}=0.9)$ correlation between the $\mathrm{EC}_{50}$ 's based on the ingestion rate of D. magna and the $24 \mathrm{~h}$ immobilisation assay.

$\mathrm{Na}^{3}$ êcz-Jawecki and Persoone (2006) modified the procedure of Rapidtoxkit so that the assay could be applied to test various dilutions of samples. In the case of 28 pharmaceuticals, an overall correlation coefficient of 0.96 between the two microbiotests was found, confirming the good predictive potential of the $1 \mathrm{~h}$ stress-based Rapidtoxkit to reveal mortality after a prolonged exposure of the crustacean test species to chemical compounds. This investigation is similar to the data collected by authors for pharmaceuticals, including both very toxic avermectins and less toxic FLU and PL. Juchelka and Snell (1994) compared the toxicity of 10 compounds using acute, chronic toxicity endpoints and ingestion rate for rotifer $B$. calyciflorus. They found out that only 4 cases the ingesition NOEC was comparable to reproduction NOEC in. As regards the other toxicants, especially metals, the ingestion test was 2.5-10 fold less sensitive. This corresponds well with he authors' findings for $T$. platyurus where ingestion was affected by 15 -fold higher levels of zinc. Moreover, Juchelka and Snell (1994) suggest that the ingestion assay was more sensitive that the $24 \mathrm{~h}$ mortality test. However, they compared the $24 \mathrm{~h} \mathrm{LC}_{50}$ values with the ingestion NOEC. The obtained data clearly shows that when comparing the same toxicity values $\left(\mathrm{EC}_{50}\right.$ with $\mathrm{LC}_{50}$ and $\mathrm{EC}_{20}$ with $\mathrm{LC}_{20}$ ), the results are similar. This high correlation means that the sublethal toxicity signal is a signal that the organisms will die, if further exposed to the toxicant for one day.

\section{CONCLUSION}

The toxicity values observed in the ingestion tests were very close to the mortality values over a wide range of toxicity from a low toxic surfactant (SDS) to very toxic avermectins. The $24 \mathrm{~h}-\mathrm{LC}_{50}$ values are within the range of $25-400 \%$ of the $1 \mathrm{~h}-\mathrm{EC}_{50}$ values for almost all toxicants tested with the exception of p-nitrophenol for $B$. calyciflorus and zinc and 3,5-dichlorophenol for $T$. platyurus. Short, $1 \mathrm{~h}$ ingestion assays RotoxRapid and Rapidtoxkit are good predictors of the mortality over the next $24 \mathrm{~h}$ and can be used as a range finding tests for representatives of pharmaceuticals and surfactants.

\section{ACKNOWLEDGEMENTS}

The authors would like to thank the Medical University of Warsaw for funding this study (Grant Number: FW14/ $\mathrm{N} / 2009$ ).

\section{REFERENCES}

ASTM, (1991). Standard guide for acute toxicity tests with the rotifer Brachionus. Annual Book of ASTM Standards, vol. 11.04, E 1440, American Society for Testing and Materials, Philadelphia, PA, USA (8 pages).

Bakoulia, P.; Karaima, C.; Rouvalis, A.; Iliopoulou-Georgudaki, J., (2008). Acute toxicity evaluation of an insecticide used in potato cultures with the use of bioassays. Fresenius Environ. Bull., 17 (8A), 1002-1006 (5 pages).

Centeno, M. D. F.; Persoone, G.; Goyvaerts, M. P., (1995). Cystbased toxicity tests. IX. The potential of Thamnocephalus platyurus as test species in comparison with Streptocephalus proboscideus (Crustacea: Branchiopoda: Anostraca). Environ. Toxicol. Water Qual., 10 (4), 275-282 (8 pages).

Dahms, H. U.; Hagiwara, A.; Lee, J. S., (2011). Ecotoxicology, ecophysiology, and mechanistic studies with rotifers. Aquat. Toxicol., 101 (1), 1-12 (12 pages).

De Coen, W. M.; Vangheluwe, M. L.; Janssen, C. R., (1998). The use of biomarkers in Daphnia magna toxicity testing. III. Rapid toxicity testing of pure chemicals and sediment pore waters using ingestion and digestive enzyme activity. Chemosphere , 37 (13), 2677-2694 (18 pages).

DellaGreca, M.; Iesce, M. R.; Isidori, M.; Montanaro, S.; Previtera, L.; Rubino, M., (2007). Phototransformation of amlodipine in aqueous solution: Toxicity of the drug and its photoproduct on aquatic organisms. Int. J. Photoenergy, art. no., 63459 (6 pages).

EPA, (2002). Methods for measuring the acute toxicity of effluents and receiving waters to freshwater and marine organisms. Fifth edition, US EPA Office of Water, EPA-821-R-02-012.

Fochtman, P.; Raszka, A.; Nierzedska, E., (2000). The use of conventional bioassays, microbiotests, and some "rapid" methods in the selection of an optimal test battery for the 
assessment of pesticides toxicity. Environ. Toxicol., 15 (5), 376-384 (9 pages).

Giri, R. R.; Ozaki, H.; Ota, S.; Takanami, R.; Taniguchi, S., (2010). Degradation of common pharmaceuticals and personal care products in mixed solutions by advanced oxidation techniques. Int. J. Environ. Sci. Tech., 7 (2), 251-260 (10 pages).

Hayes, K. R.; Douglas, W. S.; Fischer, J., (1996). Inter- and intralaboratory testing of the Daphnia magna IQ toxicity test. Bull. Environ. Contam. Toxicol., 57 (4), 660-666 (7 pages).

Isidori, M.; Lavorgna, M.; Nardelli, A.; Parrella, A.; Previtera, L.; Rubino, M., (2005). Ecotoxicity of naproxen and its phototransformation products. Sci. Total Environ., 348 (13), 93-101 (9 pages).

Janssen, C. R.; Persoone, G., (1993). Rapid toxicity screening tests for aquatic biota. 1. Methodology and experiments with Daphnia magna. Environ. Toxicol. Chem., 12 (4), 711-717 (7 pages).

Juchelka, C. M.; Snell, T. W., (1994). Rapid toxicity assessment using rotifer ingestion rate. Arch. Environ. Contam. Toxicol., 26 (4), 549-554 (6 pages).

Juchelka, C. M.; Snell, T. W., (1995). Rapid toxicity assessment using ingestion rate of cladocerans and ciliates. Arch. Environ. Contam. Toxicol., 28 (4), 508-512 (5 pages).

Kim, J. W.; Ishibashi, H.; Yamauchi, R.; Ichikawa, N.; Takao, Y.; Hirano, M.; Koga, M.; Arizono, K., (2009). Acute toxicity of pharmaceutical and personal care products on freshwater crustacean (Thamnocephalus platyurus) and fish (Oryzias latipes). J. Toxicol. Sci., 34 (2), 227-232 (6 pages).

$\mathrm{Na}^{3}$ êcz-Jawecki, G.; Persoone, G., (2006). Toxicity of Selected Pharmaceuticals to the Anostracan Crustacean Thamnocephalus platyurus. Comparison of Sublethal and Lethal Effect Levels with the $1 \mathrm{~h}$ Rapidtoxkit and the $24 \mathrm{~h}$ Thamnotoxkit Microbiotests. Environ. Sci. Poll. Res., 13 (1), 22-27 (6 pages).

$\mathrm{Na}^{3}$ êcz-Jawecki, G.; Sawicki, J., (1999). Spirotox-a new tool for testing the toxicity of volatile compounds. Chemosphere, 38 (14), 3211-3218 (8 pages).

Palma, P.; Palma, V. L.; Fernandes, R. M.; Soares, A. M. V. M.; Barbosa, I . R., (2008). Acute toxicity of atrazine, endosulfan sulphate and chlorpyrifos to Vibrio fischeri, Thamnocephalus platyurus and Daphnia magna, relative to their concentrations in surface waters from the Alentejo region of Portugal. Bull. Environ. Contam. Toxicol., 81 (5), 485-489 (5 pages).
Persoone, G., (1992). Cyst-based toxicity tests. VI: Toxkits and Fluotox tests as cost-effective tools for routine toxicity screening. Schriftenr. Ver. Wasser Boden Lufthyg. 89, $563-$ 575 (13 pages).

Preston, B. L.; Snell, T. W.; Fields, D. M.; Weissburg, M. J., (2001). The effects of fluid motion on toxicant sensitivity of the rotifer Brachionus calyciflorus. Aquat. Toxicol., 52 (2), 117-131 (15 pages).

Rapidtoxkit, (2004). Microbiotest for rapid detection of water contamination. Standard Operational Procedure. MicroBioTests Inc. Nazareth. Belgium, (19 pages). Available at://www.microbiotests.be/

Reza, R.; Singh, G., (2010). Assessment of heavy metal contamination and its indexing approach for river water. Int. J. Environ. Sci. Tech., 7 (4), 785-792 (8 pages).

Rotoxkit FTM, (2000). Rotifer toxicity screening test for freshwater. Standard Operational Procedure. MicroBioTests, Nazareth, Belgium, (20 pages). Available at: http:// www.microbiotests.be/

Sanchez-Fortun, S.; Barahona, M. V., (2005). Comparative study on the environmental risk induced by several pyrethroids in estuarine and freshwater invertebrate organisms. Chemosphere, 59 (4), 553-559 (7 pages).

Snell, T. W., (2005). Rotifer ingestion test for rapid assessment of toxicity, in: Blaise, C.; Ferard J-F. (Eds.), Small-scale Freshwater Toxicity Investigations. Vol. 1 - Toxicity Test Methods. Springer, Dordrecht, The Netherlands. (14 pages).

Snell, T. W.; Janssen, C. R., (1995). Rotifers in ecotoxicology: a review. Hydrobiologia, 313-314 (1), 231-247 (17 pages).

Snell, T. W.; Persoone, G., (1989). Acute toxicity bioassay using rotifers. II. A freshwater test with Brachionus rubens. Aquat. Toxicol., 14 (1), 81-92 (12 pages).

Snell, T. W.; Joaquim-Justo, C., (2007). Workshop on rotifers in ecotoxicology. Hydrobiologia, 593 (1), 227-232 (6 pages).

Thamnotoxkit FTM $(1995)$. Crustacean toxicity screening test for freshwater. Standard Operational Procedure. MicroBioTests Inc. Nazareth. Belgium. (23 pages). Available at: http://www.microbiotests.be/

Törökné, A.; Laszlo, E.; Chorus, I.; Fastner, J.; Heine, R.; Padisak, J.; Barbosa, F. A., (2000). Water quality monitoring by Thamnotoxkit $\mathrm{F}^{\mathrm{TM}}$ including cyanobacterial blooms. Water Sci. Tech., 42 (1-2), 381-385 (5 pages).

Törökné, A.; Vasdinnyei, R.; Asztalos, B. M., (2007). A rapid microbiotest for the detection of cyanobacterial toxins. Environ. Toxicol., 22 (1), 64-68 (5 pages).

\footnotetext{
AUTHOR (S) BIOSKETCHES

$\mathbf{N a}^{3}$ êcz Jawecki, G., Ph.D., Adjunct Professor, Department of Environmental Health Sciences, Medical University of Warsaw, Banacha 1 St., 02-097 Warsaw Poland, Email: gnalecz@wum.edu.pl

Szczêsny, f., Ph.D. Candidate, Department of Environmental Health Sciences, Medical University of Warsaw, Banacha 1 St., 02-097 Warsaw Poland, Email: Lukasz.szczesny@wum.edu.pl

Solecka, D., M.Sc., Department of Environmental Health Sciences, Medical University of Warsaw, Banacha 1 St., 02-097 Warsaw Poland, Email: daria.solecka@wum.edu.pl

Sawicki, J., Professor and Head, Department of Environmental Health Sciences, Medical University of Warsaw, Banacha 1 St., 02-097 Warsaw Poland, Email: jsawicki@wum.edu.pl 